\title{
Kuwait's Anti-Corruption Body (Nazaha): Some Aspects from the Perspective of International Law
}

\author{
Thaqal S. Al-Ajmi* \& Ali S. Alnami*
}

\begin{abstract}
This paper focuses on critical anti-corruption measures taken by the State of Kuwait and the international community, specifically as they relate to the implementation of the United Nations Convention against Corruption (UNCAC). Specific provisions of Nazaha Law, particularly those related to crimes and persons under its jurisdiction, are compared to the UNCAC, shedding light on the inherent advantages and disadvantages of the Law and whether the law constitutes a sufficient domestic anticorruption measure. By focusing on specific statutes and related jurisdictional matters, significant discrepancies between Nazaha Law and the UNCAC are noted. Kuwaiti legislators should immediately consider these discrepancies to ensure a more effective domestic policy in the global campaign against corruption. This paper comprises five parts including the Introduction and Conclusion. Part two will detail the various types of corruption covered by the Nazaha Law. Part three will focus on the persons covered under Nazaha jurisdiction. Part four will expound the issues of legal jurisdiction.
\end{abstract}

\section{Keywords}

Anti-Comuption, Kuwait, UNCAC, Convention against Corruption, Nazaha, Bribery, Crimes, Offenses, Implementation, National Law, International Law, Public Official, Money Laundering

* Associate Professor of International Law at Kuwait University Law School; Dean Assistant of Studentship Affairs at Kuwait University. LL.B. (Kuwait), LL.M. (Temple), Ph.D. (Aberystwyth). ORCID: https://orcid.org/0000-00015398-2202. The author may be contacted at: talajmi@hotmail.com / Postal Address: P. O. Box: 59191, Doha, Kuwait 93152.

** Associate Professor of International Law at Kuwait University Law School. LL.B (Kuwait), LL.M./Ph.D. (Rennes 1). ORCID: https://orcid.org/0000-0003-3907-2362. The author may be contacted at: alnamiali@hotmail.com / Address: Kuwait University, Shuwaikh, Jamal Abdulnasser Street, Kuwait 93152. All the websites cited in this article were last visited on October 19, 2020. 


\section{Introduction}

It is widely held that corruption "erodes trust, weakens democracy, hampers economic development and further exacerbates inequality, poverty, social division, and the environmental crisis. Exposing corruption and holding the corrupt to account can only happen if we understand the way corruption works and the systems that enable it." As such, the UN member states have witnessed the rapid development of efforts to combat corruption in various forms.

The essential rationale that underpins the fight against corruption, whether in the international or domestic context, involves the need to uphold the integrity of the public's confidence in governance. Other rationales include the desire to safeguard the proper functioning of public administration and the need to protect the functionality of the market and fair competition. ${ }^{2}$

Acknowledging this rationale and the international character of corruption, it became clear that an international solution was necessary. The international community finally adopted a legally binding instrument known as the United Nations Convention against Corruption (UNCAC), ${ }^{3}$ which constituted the first global instrument to embrace a comprehensive set of anti-corruption measures, including the criminalization of certain acts, to be implemented at the national level of member states. The UN Secretary-General Kofi Annan said: "The adoption of the United Nations Convention against Corruption will send a clear message that the international community is determined to prevent and control corruption. It will warn the corrupt that betrayal of the public trust will no longer be tolerated ... the adoption of the new Convention will be a remarkable achievement."

Kuwait became a state party to the instrument in 2006 by its ratification of the UNCAC through Law No. (47) of 2006 on the Approval of the United Nations against Corruption and was thus obliged to implement it and abide by those measures. Hence, one of the key steps in implementing the UNCAC was the enactment by the

1 For the comprehensive definition of 'corruption' see Transparency International, https://www.transparency.org/en/ what-is-corruption.

2 R. Rassante, The Fight against Corruption 168 (2020), https://www.adrioninterreg.eu/wp-content/uploads/2019/11/ The-Fight-Against-Corruption.pdf.

3 It was adopted by UN General Assembly on October 31, 2003 and entered into force December 14, 2005. At present, there are 140 Signatories and 187 Parties.

4 Foreword by the UN Secretary-General, Kofi Annan, to the United Nations Convention Against Corruption, Dec. 9, 2003, G.A. Res. 58/4, U.N. Doc. A/58/422 (2003), 2349 U.N.T.S 41 (2003), http://www.unodc.org/documents/treaties/ UNCAC/Publications/Convention/08-50026_E.pdf. 
National Assembly (Parliament) of Law No. (2) of 2016 on Establishing Kuwait AntiCorruption Authority and the Provisions on Disclosure of Assets and Liabilities (hereafter 2016 Nazaha Law). ${ }^{5}$

The primary purpose of this study is to elaborate the role of the Kuwaiti AntiCorruption Authority (Nazaha) in matters of its jurisdiction rationae materiae (i.e., the scope of crimes it is concerned with), its jurisdiction personae (i.e., persons subject to its law), and its legal competence to seize and investigate. The aspects of Nazaha will be evaluated under the applicable rules of international law. This paper comprises five parts including the Introduction and Conclusion. Part two will detail the various types of corruption covered by Nazaha Law. Part three will focus on the persons covered under Nazaha's jurisdiction. Part four will expound on the issues of legal jurisdiction that Nazaha may encounter.

\section{Ratione Materiae}

This section addresses the various types of corruption covered by Nazaha Law. It is to be noted that the commission of enlisted crimes should theoretically trigger the jurisdiction of Nazaha and entail specific procedures that will be detailed later. Specifically, this section references Article 22 of Nazaha Law, which clearly states that the Law shall apply to offenses against public funds, offenses of bribery and abuse of power, money laundering, the financing of terrorism, counterfeiting, and forgery.

\section{A. Offenses against Public Funds}

Offenses against public funds are the first crime with which Nazaha Law is concerned, owing to its presence in Kuwaiti jurisprudence since 1993. As stated in the Law No. (1) of 1993 on the Protection of Public Funds (hereafter 1993 Law), offenses against public funds may manifest in any of the following situations:

- Embezzlement by a public official, servant, or worker of money, documents,

5 Law No. (2) of 2016 on Establishing Kuwait Anti-Corruption Authority and the Provisions on Disclosure of Assets and Liabilities. To note, the first anti-corruption authority in Kuwait was established in 2012 through the enactment of Law Decree No. 24 of 2012 on Establishing Kuwait Anti-Corruption Authority and the Provisions on Disclosure of Assets and Liabilities. However, this Decree was abolished by the Kuwait Constitutional Court on December 20, 2015, upon holding that the issuance of the Law violated the regulations and restrictions stated in the Constitution of Kuwait (Constitutional Judgment No. 24 of 2015, Dec. 20, 2015). 
equipment, or other items entrusted to them as part of their job; ${ }^{6}$

- Unlawful seizure (or facilitation thereof) by public official, servant, or worker of money, documents, or equipment belonging to the State, public bodies, and public institutions, and companies and establishments in which the entities mentioned above contributed at least $25 \%$ of their capital directly or indirectly; ${ }^{7}$

- Abuse of trust by a public official, servant, or worker assigned to maintain the interest of the entities mentioned above and engagement in deals, transaction, cases, or negotiations to link, agree, or contract with any entity-whether inside or outside the country-in matters that will acquire rights or endure financial obligations to the State or other entities mentioned above, and which they intentionally conduct in a manner that harms the interests of these entities to obtain profits or benefits for themselves or others; ${ }^{8}$

- Unlawful gains or benefits by a public official, servant, or worker involved in management of contracts, supplies, or works related to any entities mentioned above or in supervision over it, who obtained or tried to obtain for themselves or others unlawful gains or benefits; ${ }^{9}$

- Disclosure of confidentiality by a public official, servant, or worker about the works of the entities mentioned above that should remain confidential by their nature or per special instructions if such disclosure will harm the interests of these entities or achieve personal benefit for anyone; ${ }^{10}$ and

- Malpractice, negligence, abuse of authority, or breach of duty by a public official, servant, or worker, causing severe harm to the assets or interests of the entity for whom they work, connected to or by virtue of their job or causing damages to the country's financial, commercial, or economic status. ${ }^{11}$

The 1993 Law is broader than the provisions included in the UNCAC in some aspects as the UNCAC is limited to the criminalization of embezzlement, misappropriation of funds, or other property diversions by a public official; ${ }^{12}$ whereas the 1993 Law encompasses embezzlement, unlawful seizure, abuse of trust, unlawful gain, disclosure of confidentiality, malpractice, negligence, abuse of authority, and breach of duty concerning public funds.

Although the UNCAC and the 1993 Law both criminalize the embezzlement of properties, funds, securities, or any other items of value that are entrusted to public officials by virtue of their position, the UNCAC includes "misappropriation or

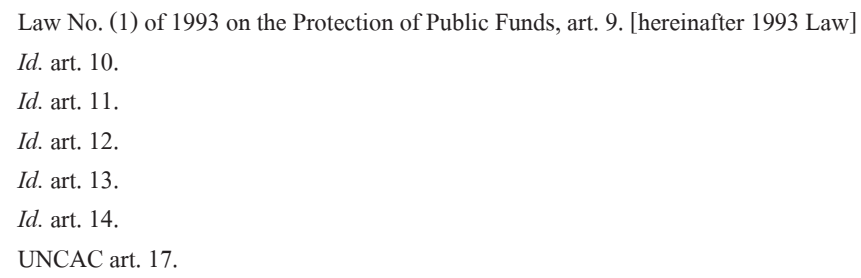


other diversions of property by a public official" among the criminal acts, which has broader implications and may include any unauthorized or improper use of property for any purpose other than that intended. On other words, the UNCAC is not confined only to embezzlement, i.e. the unlawful taking of property and acquisition of property due to a person's position or employment. ${ }^{13}$ Therefore, the UNCAC diverges from the Law on the Protection of Public Funds on some critical points.

The UNCAC criminalizes the embezzlement of property in the private sector by obliging States to recognize embezzlement as a criminal offense "in the course of economic, financial or commercial activities ... by a person who directs or works, in any capacity, in a private sector entity of any property, private funds or securities or any other thing of value entrusted to him/her under his/her position."14

Unlike Article 22 of the UNCAC, the 1993 Law is confined to offenses against public funds, defined as money or assets owned or subjected by law to the administration to any of these entities, regardless of their position inside or outside the State. Hence, Article 2 governs the following:

- The State;

- Public bodies and public institutions; and

- Companies and establishments to which the abovementioned entities contributed at least $25 \%$ of their capital whether directly or indirectly through companies or enterprises in which the State, public bodies, public institutions, or other public juridical persons contribute a share in their capital. ${ }^{15}$

Any offenses against private property or property of companies and establishments to which entities mentioned in Article 2 contribute less than 25\% lie beyond the scope of the 1993 Law. This does not mean that these offenses are not criminalized by other provisions of the Kuwaiti Penal Code. Rather, they will not be considered the corrupt acts under the 2016 Nazaha Law as prescribed by the UNCAC. ${ }^{16}$

In addition to the procedures of seizure and investigation that Nazaha Law includes, ${ }^{17}$ there are serious implications of considering an offense to be a crime under the 2016 Nazaha Law. In particular, the statute of limitations - as articulated under

13 Black's Law Dictionary 522 (6th ed. 1997).

14 UNCAC art. 22.

15 To determine the percentage of the capital mentioned above, reference must be made to the total shares of the State or other bodies with public juridical personality or companies referred to. See Law No. (1) of 1993 on the Protection of Public Funds art. 2.

162016 Nazaha Law art. 4(2).

17 This chapter of the law concerns the procedures of seizure, confiscation, recovery of funds, and proceeds of corruption offenses, and access to records, papers, and documents related to the offenses listed in the Law. 
Article 54 - states that all criminal offenses listed in the Law "shall not be abated and the adjudged penalty for such offenses shall not be barred by prescription."18

\section{B. Offenses of Bribery and Abuse of Power:}

Other significant offenses that fall within Nazaha's jurisdiction are bribery and the abuse of power, as outlined in Law No. (31) of 1970 (hereinafter 1970 Penal Code), amending some provisions of the Penal Code No. (16) of 1960. These crimes are punishable by law if committed by any public official who performs any or all of the following acts:

- Requesting or accepting any gift, whether for themselves or someone else, in return for acting or refraining from acting in the exercise of official duties. ${ }^{19}$ This is the case even if the requested work does not fall within the exercise of their official duties or they mistakenly or allegedly believe that it does. ${ }^{20}$

- Unlawful performance or nonperformance of an act in the exercise of their official duties because of a gift or gratuity after accomplishing the performance or nonperformance of an act that was conducted solely for this appreciation. ${ }^{21}$

- Requesting for themselves or another a promise or gift as an alleged bribe for a public official with the intention of maintaining it in whole or in part for themselves or to use a real or supposed influence to gain or try to gain from any public authority of works, orders, judgments, decisions, medals, commitment, license, agreement of supply, contracting, job, service, or any virtue whatsoever. ${ }^{22}$

- Punishment will be the same for the bribing party, bribed party, and the intermediary if any. ${ }^{23}$

- Offering a public official who has refused such an offer a promise or a gift in return for acting or refraining from acting whether or not it is in violation of their official duties. $^{24}$

Notably, the offenses of bribery and abuse of authority attract strict penalties and rigorous enforcement under Kuwaiti law, particularly with respect to bribery. Like the UNCAC, the 1970 Kuwaiti Penal Code criminalizes active bribery (i.e., offering

18 Id. art. 54.

19 Law No. (31) of 1970, art. 38 [hereinafter 1970 Kuwaiti Penal Code] (amending some provisions of the Kuwaiti Penal Code No. (16) of 1960). [hereinafter 1960 Kuwaiti Penal Code]

201970 Kuwaiti Penal Code, art. 35.

21 Id. art. 36.

22 Id. art. 37.

23 Id. art. 39.

24 Id. art. 41. 
or paying for a bribe) ${ }^{25}$ as well as passive bribery (i.e., receiving a bribe). ${ }^{26}$ Similar to the UNCAC, the bribe is criminalized whether the benefit is direct (i.e., for the bribed person) or indirect (i.e., for another person). However, neither the Kuwaiti law on bribery nor the UNCAC requires the bribe's beneficiary to retain the gift for a specific time. Therefore, technically, the involuntary receipt of a present returned immediately would not constitute bribery under any provision. ${ }^{27}$ More importantly, Kuwaiti law on bribery is similar to the UNCAC in that it does not provide exceptions for the facilitation of payments. ${ }^{28}$ When it comes to these so-called "facilitation payments" (also known as "grease payments"), money and gifts are intended to expedite the procedures or secure the performance of a routine governmental action. ${ }^{29}$

Unlike, for example, the US federal law-Foreign Corrupt Practice Act (FCPA)which excludes any person who paid a bribe abroad, ${ }^{30}$ if the payment of money, gifts, or benefits are otherwise lawful in the foreign official's country, this would constitute an affirmative defense for the defendant. ${ }^{31}$ However, Kuwaiti law on bribery is silent on this matter. A similar finding emerges with regard to Kuwaiti criminal law as it is primarily concerned with territorial jurisdiction (i.e., connection to Kuwaiti

25 The distinctions between "offering," "promising," and "giving" bribes need to be highlighted. "Offering" occurs when a briber indicates that they are ready to provide a bribe. "Promising" concerns a briber who agrees with the official to provide a bribe (e.g., where the briber agrees to a solicitation from the public official). "Giving" occurs when the briber actually transfers the undue advantage. See OECD Glossaries, Corruption, A Glossary of International Standards in Criminal Law 26 (2008), https://www.oecd.org/daf/anti-bribery/41194428.pdf.

26 Árni Múli Jonasson, International Law against Corruption - An Icelandic Perspective (2005) (Master's Thesis, The University of Lund), at 11, https://lup.lub.lu.se/luur/download?func=downloadFile\&recordOId=1554916\&fileO $\mathrm{Id}=1563486$. See also United Nations Office Drugs and Crimes, The Global Programme against Corruption, UN AntiCorruption Toolkit, at 11-12 (2d ed. 2004), https://www.unodc.org/documents/corruption/Toolkit_ed2.pdf.

27 J. Wouters, C. Ryngaert, \& A. Sofie Cloots, The Fight Against Corruption in International Law 45 (Leuven Centre for Global Governance Studies Working Paper No. 94, July 2012), https://papers.ssrn.com/sol3/papers.cfm?abstract $\mathrm{id}=2274775$. See also M. Kubiciel, Core Criminal Law Provisions in the United Nations against Corruption, 9(1) INT'L Crim. L. Rev. 147 (2009).

28 T. Snider \& W. Kidane, Combating Corruption through International Law in Africa: A Comparative Analysis, 40 CORNELl INT'L L. J. 730 (2007).

29 Id. at 730. See also A. Posadas, Combating Corruption Under International Law, 10 DuKe J. Comp. \& INT'L L. 361 (2000); Wouters et al., supra note 27, at 37; Kubiciel, supra note 27, at 154.

30 The Foreign Corrupt Practices Act of 1977 (FCPA) 15 U.S.C. § 78dd-1 et seq. The FCPA defines the term "routine governmental action" as an action which is ordinarily and commonly performed by a foreign official in obtaining permits, licenses, or other official documents to qualify a person to conduct business in a foreign country; processing governmental documents, etc. See also S. Deming, 31 Foreign Corrupt Practices, 33 InT'L Law. 507 \& 514 (1999); J. Colares, The Evolving Domestic and International Law against Foreign Corruption: Some New Dilemmas Facing the International Lawyer, 5 Wash. U. Global Stud. L. Rev. 1-30 (2006); F. Heinemann \& M. Hirsch, How International Business Combats Extortion and Bribery: Anti-Corruption Efforts by the International Chamber of Commerce, in No Longer Business as Usual, Fighting Bribery and Corruption 170 [OECD, 2000], http://www.oecd.org/daf/antibribery/nolongerbusinessasusual-fightingbriberyandcorruption.htm.

31 Snider, id. at 731. See also FCPA, id. § 78dd-1(c)(1); Posadas, supra note 29, at 362; Wouters et al, supra note 27, at 38. 
territory), ${ }^{32}$ or personal jurisdiction (i.e., the nationality of the accused), provided that the act is subject to the dual criminality condition. ${ }^{33}$ Therefore, these provisions stand in contrast to the UNCAC, which is intended to illegalize bribery wherever committed by securing high acceptance from various nation-states worldwide.

One further glaring shortcoming of Kuwaiti anti-bribery law that the 2016 Nazaha Law relies upon is the prerequisite of the existence of a public official, in order to exercise jurisdiction over the bribery offenses mentioned above. A "public official" is defined to include:

- Employees, servants, and workers in interests affiliated with the government of Kuwait or subjected to its supervision or control;

- Members of public or local representative councils, whether elected or appointed;

- Arbitrators, experts, creditor managers, liquidators, and public trustees;

- Any person assigned with public service; and

- Members of the board of directors, directors, employees, and servants of institutions, companies, associations, organizations, and establishments in which the government or any of its public authorities participate or share in the property of, regardless of its capacity. ${ }^{34}$

At first glance, the definition of public official under Kuwaiti criminal law may appear overly broad including many categories of people. Concerning the crime of bribery as prescribed by the UNCAC, however, this definition is far from inclusive of all types of bribery involving public officials, whether as an immediate victim or perpetrator of this crime.

According to the UNCAC, in addition to bribery of national public officials, ${ }^{35}$ bribery of foreign public officials ${ }^{36}$ and officials of public international organizations ${ }^{37}$ is criminalized. ${ }^{38}$ Therefore, any bribery involving a foreign public official, who is

33 Id. art. 12.

341970 Kuwaiti Penal Code, art. 43.

35 UNCAC art. 15. See also A. Argandoña, The United Nations Convention Against Corruption and Its Impact on International Companies 4-5 (IESE Business School Working Paper No. 656, Oct. 2006), https://papers.ssrn.com/sol3/ papers.cfm?abstract_id=960662.

36 UNCAC art. 2 (b) (whereby a foreign public official is "any person holding a legislative, executive, administrative or judicial office of a foreign country, whether appointed or elected; and any person exercising a public function for a foreign country, including for a public agency or public enterprise.")

37 UNCAC art. 2(c) (where by an official of a public international organization is defined as "an international civil servant or any person who is authorized by such an organization to act on behalf of that organization.")

38 UNCAC art. 16. It should be noted that for corrupt acts involving public officials or officials of public international organizations, however, a distinction is made between active and passive bribery. To be covered by UNCAC, active bribery should involve an official act (or failure to act) in the exercise of the foreign public official's duties for the purpose 
not working for the Kuwaiti government directly or indirectly and is not performing work with an assigned public service-even if it occurs in the territory of Kuwait-is not considered to be a criminal act under the anti-bribery law. It is not subject to the jurisdiction of Nazaha, either.

This is also the case if the act of bribery involves officials of public international organizations and if the Kuwaiti government has no stakes in the budget, assets, or properties of the organization. Furthermore, the Kuwaiti definition of a public official must be met as a precondition, whether the act of bribery has occurred inside the nation's borders or beyond.

The situation is intensified for private sector bribery, especially under the UNCAC. $^{39}$ Kuwait lacks regulations or laws on this issue, allowing private sector bribery in Kuwait to effectively enjoy full legal tolerance, whether it involves active or passive bribery. ${ }^{40}$

\section{Offenses of Money Laundering and the Financing of Terrorism}

Money laundering and terrorism financing are among the offenses that the 2016 Nazaha Law is concerned with and exercises jurisdiction over them. Money laundering was criminalized in 2013, seven years after Kuwait's ratification of the UNCAC in 2006. The legislators took the UNCAC's definition of money laundering into account while creating other similar provisions. Both the UNCAC and Kuwaiti laws criminalize any person who knows that the property ${ }^{41}$ involved represents the proceeds of a crime ${ }^{42}$ or who intentionally commits any of the following actions:

of obtaining or retaining business or other undue advantages concerning the conduct of international business, whereas for passive bribery (solicitation or acceptance of bribe), States Parties shall "consider" criminalizing such solicitation or acceptance, whether or not this is related to business transactions. See Wouters et al., supra note 27, at 45-6.

39 UNCAC art. 21.

40 A classic example of corruption in the private sector is extortion of bribery by managers of supermarket chains from suppliers for access to the chains or the provision of illegal financial services. See International Anti-Corruption Academy (IACA) Report prepared by Prof. Eduard Ivanov, Preventing, and Combating Corruption (Summary Report of IACA's Tailor-Made Anti-Corruption Course for Experts from Russia, Armenia, Belarus, Kazakhstan, and Kyrgyzstan 23-25 Sept. 2019), at 5 (2019), https://www.iaca.int/media/attachments/2020/03/06/report-2019.pdf.

41 Property denotes any kind of funds or assets, whether money, commercial or financial papers, corporeal or incorporeal properties, immovable or movable or related rights thereto however acquired, and documents, legal instruments in any form, including digital or electronic, or banking credit facilities, checks, payment orders, stocks, bonds, promissory notes, and letter of credits, whether inside or outside the country. See Anti-Money Laundering and Combating the Financing of Terrorism Law No. (106) of 2013, art. 1. [hereinafter 2013 Kuwaiti Anti-Money Laundering Law]

42 R. Booth et al., Money Laundering Law and Regulations: A Practical Guide 3-4 (2011). The money laundering operation has three phases:

(i) Placement: the initial entry of the illicit money into the financial system of the State concerned;

(ii) Layering: the process by which the money is separated from its sources, often using anonymous shell companies; and 
- Converts or transfers property to conceal or disguise the illicit origin of the property; - Assists any person who is involved in the commission of the predicate offense to evade the legal consequences;

- Conceals or disguises the actual nature, source, location, disposition, movement, or ownership of or rights concerning property; or

- Acquires, possesses, or uses the property concerned. ${ }^{43}$

Kuwait's anti-money laundering law also criminalizes terrorist financing, which occurs when "any person ... by any means, directly or indirectly, unlawfully and willfully, collects or provides funds, with the knowledge that they will be used or with the intent that they should be used, in full or in part, to carry out a terrorist act or for the benefit of a terrorist organization or of a terrorist ... even if the terrorist act does not occur, or if the funds are not used to commit or attempt the act or if the funds are not linked to a specific terrorist act."

Thus, according to Nazaha Law, this anti-corruption authority will exercise its jurisdiction over terrorism financing offenses, as defined above. This may be because terrorism financing is a serious crime that, along with money laundering, is detrimental to the economic and financial system of the State concerned, as it is aimed at obscuring properties of legal origin (such as public funding or charities).

\section{Offenses of Counterfeiting and Forgery}

More crimes are subject to the material jurisdiction of Nazaha than previously noted, including crimes of forgery and counterfeiting, which are articulated in the 1960 Kuwaiti Penal Code. According to this Code, the crime of forgery will occur in any of the following cases:

- When a change is made to the essential nature of an official document for use as an authentic document, if it is usable for that purpose after the change;

- When the modified document is made by the beneficiary him/herself and attributed to another person who did not issue it, whether the change is made by the addition of some of its words, the deletion of such, or mere changing of the words;

- When there is a signature, stamping, unauthorized fingerprinting, or fraudulent action in making a person sign, stamp, or finger-print a document without their knowledge of its accurate contents or without their true agreement;

(iii) Integration: the money's return to the criminal from seemingly legitimate sources.

43 UNCAC art. 23; 2013 Kuwaiti Anti-Money Laundering Law, supra note 41, art. 2.

442013 Kuwaiti Anti-Money Laundering Law art. 3. 
- When the person entrusted with writing a document changes its real meaning by adding false information to it;

- When the person entrusted with writing a document is abused by another person who fraudulently dictates incorrect details to be presented in the document as truthful; ${ }^{45}$

- When a document forged by others is knowingly used; ${ }^{46}$

- When an official document that lacks its legal force because of its revocation, canceling, replacement, suspension, or expiration is used intentionally and with full knowledge for the deception that the document is still of legal force; ${ }^{47}$ or

- When a person entrusted with a signed or stamped blank document breaches that trust and writes a debt deed, discharge, or any deeds that incur harm for the signed or stamped person. ${ }^{48}$

Concerning the crimes of counterfeiting, the 1960 Kuwaiti Penal Code prescribes these actions:

- Feigning banknotes by making false banknotes look genuine;

- Forging banknotes by changing them and using the forged ones in trading; ${ }^{49}$

- Knowingly using, trading, circulating by any means, or bringing into the country forged or counterfeited banknotes; ${ }^{50}$

- Knowingly manufacturing, participating in manufacturing, repairing, or bringing into Kuwait a machine, device, note, or any material used to counterfeit or forge banknotes;

- Making false coins that look similar to genuine ones;

- Forging coins by decreasing their value by any means;

- Plating coins to make them look like high-value coins with the intention of using them to trade ${ }^{51}$

- Knowingly circulating, using, or bringing into the country counterfeited coins; ${ }^{52}$ or

- Knowingly manufacturing, participating in manufacturing, repairing, or bringing into Kuwait a machine, device, note, or any material used in counterfeiting or forging coins. ${ }^{53}$ 
The subjection of all these criminalized actions to the jurisdiction of Nazaha will significantly support combating corruption due to the sheer proliferation and complexity of the crimes, which are not included under any of UNCAC's provisions. The only possible justification for the inclusion of these crimes under Nazaha would be to protect the country's financial and economic system.

\section{E. Offenses Relating to the Administration of Justice}

According to Article 22 of Nazaha Law, crimes related to the administration of justice outlined in the 1960 Kuwaiti Penal Code are included in the list of crimes subject to the jurisdiction of such Law. These crimes include perjury, false notifications, and more, as outlined in the sub-sections that follow.

\section{Perjury}

According to the 1960 Kuwaiti Penal Code, perjury occurs when a person required to give testimony before any judicial entities under oath knowingly gives false information. ${ }^{54}$ Perjury also includes any person who was entrusted with tasks requiring expertise or translation skills but who intentionally alters the truth. ${ }^{55}$ Both forcing a witness to refrain from testifying or pressuring them to deliver a false testimony, ${ }^{56}$ and knowingly giving false information before non-judicial entities are instances of perjury. ${ }^{57}$

2. Refrain from Testimony or Failure to Render the Requested Assistance to the Judiciary Persons are not allowed to refrain from giving testimony without reasonable justification when such persons are enlisted to present before the judiciary. ${ }^{58}$ The destruction of evidence or documents relevant to judicial procedures, making it impossible to derive the necessary details for the adjudication of an ongoing case or a case that is pending, is also forbidden. ${ }^{59}$ Moreover, it is forbidden for any person required to be present before an official with judicial competence to refrain from this duty without reasonable justification. ${ }^{60}$

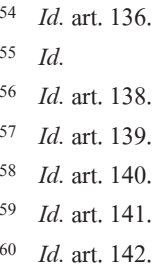




\section{False Notification}

If a law enforcement official falsely states that a person has committed a punishable act and it transpires that this information is untrue, even if the official is deemed incompetent or took no actions were taking, s/he is said to give a "false notification," which is covered under the 1960 Kuwaiti Penal Code. ${ }^{61}$ Moreover, disturbing public authorities, administrative entities, or persons assigned with public service with false reports of disasters, accidents, or risks is also covered by the Code. ${ }^{62}$

\section{Influencing Judicial Entities or Offending their Reputations}

This sub-section covers any person who maliciously attempts by order, request, threat, pleading, or recommendation to induce an official with judicial competence to engage in unlawful procedures or refrain from taking lawful due procedures. ${ }^{63}$ The crime of offending the reputation of judicial entities occurs when any person violates, through publicity, the due respect of a judge by questioning their integrity, dedication to work, or commitment to laws. ${ }^{64}$

\section{Breaking of Seals}

This crime occurs when a person intentionally breaks seal on documents or items that was placed to save them in particular locations, as requested by judicial order or judgment. ${ }^{65}$ In comparison with the relevant UNCAC provisions, these provisions criminalize specific acts (i.e., the use of physical force, threats, intimidation, or the promise of offering, or giving of an undue advantage, etc.) directed against the witness by another person. At the same time, the Kuwaiti Penal Code covers cases where the witness is the sole actor of the false testimony. This will be the case even if the person is not a witness, for example, if they are assigned tasks requiring translation or expertise skills and altering the truth. Other provisions of the UNCAC are limited to acts related to evidence or a justice or law enforcement official. ${ }^{66}$ By contrast, the 1960 Kuwaiti Penal Code is significantly comprehensive as it covers other acts, such as false notification or the breaking of seals. However, offenses of illicit gain are also covered under the Code.

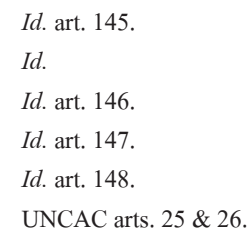




\section{F. Offenses of Illicit Gain}

Offenses of illicit gain are new crimes articulated in the 2016 Nazaha Law, which did not previously exist in Kuwaiti legal jurisprudence. As defined by the 2016 Nazaha Law, illicit gain is "any increase in the wealth or diminution of liabilities occurs because of assuming an office or a capacity-to the official subject to this law, his [her] minor children or those under his [her] guardianship, custodianship or curatorship whenever it is disproportionate to their sources, and it is unjustified." ${ }^{\prime 67}$

In contrast, the UNCAC states that crimes of illicit gain are considered to be intentional when there "is a significant increase" in the assets of a public official that s/he cannot reasonably explain with his/her lawful income. ${ }^{68}$ The 2016 Nazaha Law and the UNCAC differ in many ways, some of which are crucial and may constitute apparent variations from the international community's goals in adopting the UNCAC. These differences are described in the following paragraphs.

First, the UNCAC requires an "intention" when a crime is committed (i.e., someone willfully and deliberately acting a certain way), whereas Nazaha Law is silent on this matter. Therefore, the crime of illicit gain exists under Nazaha Law, even if the intention of the person's concern is not explicit.

Second, the UNCAC requires the increase in assets to be "significant" for the crime of illicit gain to have occurred, whereas the Nazaha Law does not stipulate an increase in assets of any specific description. Hence, according to the Nazaha Law, any increase in assets, even though minor, may trigger the criminalization of its provisions.

Third, the UNCAC mentions only the increase of assets as the sole manifestation of illicit gain crime, whereas Nazaha Law includes the "diminution of liabilities" as another manifestation of the crime of illicit gain. As a brilliant step, this covers the case where a public official, instead of taking money as bribery, directs the money toward any of his/her financial obligations (like debts or mortgages).

Fourth, the illicit offense prescribed in the UNCAC applies to any public official as defined by Article 2 of the Convention, which includes any public official regardless of their superiority or rank or the services they are performing (i.e., legislative, executive, administrative, or judicial). By contrast, illicit gain under the Nazaha Law applies to a narrow list of public officials, depending on their positions, the services they provide, or their superiority, as will be discussed later. Therefore, it is not a crime of illicit gain if the increase of unjustified assets occurs with respect to a public 
official who is out of the list of public officials under Nazaha Law, but a crime under the UNCAC.

Fifth, under Nazaha Law, the increase of assets or the diminution of liabilities must occur for the listed public officials as a result of their having assumed offices or capacities. The UNCAC, however, has no apparent requirement for such a connection between the increase of assets and the public official's assumption of office or capacity. Nevertheless, such a connection is presumed; otherwise, the UNCAC would designate this as a crime that anyone can commit (like money laundering), but not a crime that can only be committed by a public official.

Finally, under the Nazaha Law, the crime of illicit gain occurs even if the direct beneficiaries of the unjustified increase of assets (or the diminution of liabilities) are not the listed public officials but their minor children or those under their guardianship, custodianship, or curatorship. ${ }^{69}$ By contrast, the UNCAC mentions only the public official and no others. This may not be considered a loophole in the UNCAC's provisions regarding the crime of illicit gain, because the increase in the assets of the public official's minor children or those under their guardianship, custodianship, or curatorship will be attributed to the public official, who will be held accountable as long as these assets can be traced to them. Moreover, the actions of other people who may help to hide unjustified assets are covered by Article 24 of the UNCAC, which criminalizes the act of concealment concerning the properties that resulted from any corrupted acts stated therein. ${ }^{70}$

Ultimately, the crime of illicit gain is a particularly controversial criminal offense because it shifts the burden of proof onto the defendant and may be considered a violation of the presumption of innocence, which is incorporated into many national constitutions. For this reason, both the US and Canada made similar provisions in the Inter-American Convention against Corruption (IACAC). ${ }^{71}$

69 It should be noted that the spouses of the listed public officials are also mentioned in Article 48 of the 2016 Nazaha Law, which states: "Whoever commits the offense of Illicit Gain shall be punished ... whether it was in his account or the account of his spouse or minor children or those under his guardianship or curatorship..."

70 UNCAC art. 24 (stating: “... Each State Party shall consider adopting such legislative and other measures as may be necessary to establish as a criminal offense when committed intentionally after the commission of any of the offenses established by this Convention without having participated in such offenses, the concealment or continued retention of the property when the person involved knows that such property is the result of any of the offenses established by this Convention.")

71 Snider \& Kidane, supra note 28, at 728. See also Senate Resolution on Inter-American Convention on Corruption, S. REP. No. 106-7809 (2000). The presumption of innocence is so fundamental that its disregard would violate the US Constitution, particularly the Fifth Amendment and the Due Process Clause. Under the Due Process Clause, the prosecution must prove each offense's element beyond a reasonable doubt. See, e.g., In re Winship, 397 U.S. 358,364 (1970). The U.S. Constitution prohibits the shifting of this burden to the criminal defendant. See, e.g., Patterson v. New York, 432 U.S. 197, 210 (1977). Canada's iteration reads: "As the offense contemplated by Article IX would be 


\section{G. Offenses of Evasion of Customs Duties}

Kuwaiti legislators also included offenses of evasions of customs, as outlined in Law No. (10) of 2003 on the Promulgation of the United Customs for the Arab States of the Gulf Cooperation Council (hereinafter Law No. (10)), under Nazaha's jurisdiction.

As defined in the Law No. (10), smuggling refers to bringing or attempting to bring goods into or out of the country wholly or partly in contravention of the applicable laws without paying customs taxes and duties or in contravention of the provisions of restriction or prohibition provided for therein or in other laws. ${ }^{72}$ The Law No. (10) outlines various instances of smuggling, including the following:

- Failure to take goods to the first Customs Office upon entry;

- Failure to adopt the procedures stated for entry or exit of goods;

- Unloading goods from or loading goods onto vessels in a manner contrary to regulations at the customs offices, or unloading or loading goods within the sea customs zone;

- Illegally unloading goods from or loading goods onto aircraft outside official airports or dumping goods during air transport;

- Failure to declare goods that have entered or exited the country without the Cargo Statement Manifest at the Customs Office, including goods of a commercial character carried by passengers;

- Taking undeclared goods into or out of the Customs Office;

- Discovery at the Customs Office of undeclared goods that have been concealed, for example, in hollow or empty spaces that are not ordinarily allocated to the storage of such goods;

- Increase, reduction or alteration of the number or contents of declared parcels;

- Taking goods out of free zones and shops or customs stores or warehouses or customs zones without processing customs formalities;

- Submission of false or forged or fabricated documents or placement of false marks to evade payment of customs taxes, duties, or restrictions;

- Transport or possession of prohibited or restricted goods without submission of proof to support the legal import thereof;

- Transport or possession of goods subject to the authority of customs within the customs zone without legal documentation; or

- Failure to re-import goods that have been banned from export and that were

contrary to the presumption of innocence guaranteed by Canada's Constitution, Canada will not implement Article IX, as provided for by this provision." For the alternative view that illicit-enrichment clauses impose only an evidentiary burden on a defendant and do not remove the prosecutor's legal burden, see generally N. Kofele-Kale, Presumed Guilty: Balancing Competing Rights and Interests in Combating Economic Crimes, 40 InT'L Law. 909 (2007). See also Wouters et al, supra note 27 , at 43 .

72 Law No. (10) of 2003 on the Promulgation of the United Customs for the Arab States of Gulf Cooperation Council, art. 142 . 
temporarily exported for any purpose whatsoever. ${ }^{73}$

Clearly, these offenses are not limited to public officials in the 2016 Nazaha Law, although they would be committed by any person involved in the import or export of goods. This may include, as the Law No. 10 prescribes, the owners of the means of transport used for smuggling, the drivers and assistants involved, the owners or tenants of the premises in which smuggled goods are stored, or the beneficiaries who are proven to have been aware of the presence of smuggled goods in their premises or shops. $^{74}$

One may ask why Kuwaiti legislators cast over burden on the new national anticorruption authority (Nazaha) with a long list of offenses that are neither considered to constitute corruption, nor even mentioned in the UNCAC, which Nazaha is intended to implement. The only apparent reason that the connection between these crimes of customs evasion and other listed crimes in the 2016 Nazaha Law is that they are also crimes against the country's financial and economic systems, which must be protected and observed.

\section{H. Offenses of Tax Evasion}

Another offense related to the act of evasion is tax evasion, which, according to Nazaha Law, is subject to Kuwait's jurisdiction. As outlined in Decree No. (3) of 1995 concerning Kuwait Income Tax, tax evasion offenses involve the act of knowingly falsifying the taxpayer's record or making false statements that affect any declaration certificate required for the Decree. ${ }^{75}$

According to this Law, income tax, which is $15 \%$ of net taxable income, is imposed on everyone considered corporate, wherever incorporated, conducting a trade or business involving activities inside Kuwait. Further, the profits realized from any contract may be totally or partially completed in Kuwait. It also includes the amounts collected from the sale or lease, granting a franchise to use or exploit any trademark, patent design, or copyright; commissions due or resulting from representation agreements or commercial mediation; profits from industrial and commercial businesses; profits realized from disposal of assets; profits resulting from the purchase and sale of properties, goods, related rights, and the opening of a permanent office in Kuwait wherein sale and purchase contracts are concluded; profits resulting from the

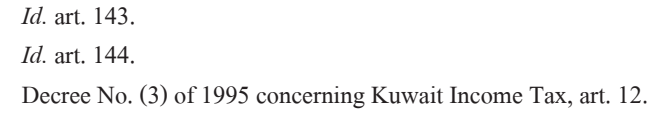


lease of any properties; and profits resulting from rendering any services. ${ }^{76}$

Evidently, more offenses that are not considered corrupt crimes under the UNCAC are nonetheless subject to Nazaha's jurisdiction. The only justification for this would seem to protect the country's commercial and financial system and safeguard its proper functioning for the greater public good.

\section{Offenses against Nazaha}

To protect the Anti-Corruption Authority's integrity and safeguard its works against any interference, the Nazaha Law criminalizes several actions, including the following:

- Obstructing Nazaha's work;

- Putting pressure upon Nazaha to impair the performance of its duties;

- Interfering in Nazaha's competence; or

- Failure or refusal to provide Nazaha with any requested information. ${ }^{77}$

Unfortunately, the Nazaha Law does not elaborate on these prescribed actions, but only the latter action-failure to provide required information-is detailed further, with the clarification that when Nazaha suspects that an act of corruption has been committed, it will collect information by accessing, as necessary, records, papers, and documents related to the offense and may request any relevant data, information, or documents. ${ }^{78}$

Another provision of Nazaha Law states that the "agencies affiliated to the public or private sectors or any natural or legal person may not do any of the following acts: 1- Refuse, without legal justification, to provide the Authority with any records, documents, papers or information that may be useful for the whistleblowing of acts of corruption." 79

In the case of a suspected offense of illicit gain, Nazaha states that the government can "secretly request data, explanation, and papers that it deems to be necessary from individuals, governmental or private entities inside and outside Kuwait." ${ }^{80}$ Failure to

76 Id. art. 1.

772016 Nazaha Law art. 22.

78 Id. art. 24.

79 Whoever breaches this provision shall be punished by imprisonment for a period not more than three years and a fine of not less than two thousand Kuwaiti dinars and not exceeding ten thousand Kuwaiti dinars or by one of these penalties. See 2016 Nazaha Law art. 45.

$80 \quad$ Id. art. 34. 
file this information is punishable by law. ${ }^{81}$

Regarding offenses that obstruct the work of Nazaha, one may cite the provisions related to whistleblowers with respect to preventing the disclosure of their identities or domiciles. ${ }^{82}$ Alternatively, they may be punished for having intentionally provided false information, concealed information, committed fraud or deception, concealed the truth, or misled justice. ${ }^{83}$

\section{J. Offenses of Unlawful Acts of Competition}

Another set of crimes included under Nazaha's jurisdiction is articulated in Law No. (10) of 2007 on the Protection of Competition. This law is designed to secure the freedom to practice economic activity by all means that do not lead to restricting, hindering, or harming free competition. ${ }^{84}$

Under the Law No. (10) of 2007, any agreements, contracts, practices, or decisions that harm free competition are prohibited, and the dominant natural or juridical persons have prohibited the abuse thereof, as follows:

- Influencing the prices of products that form the object of dealings by increasing, decreasing, or stabilizing such prices or by sham or bogus transactions or in any other manner that acts against the market mechanism to harm other competitors;

- Wholly or partly restricting the free inflow or outflow of products on the market by concealing or refraining from dealing in or storing such products illegally, or in any other manner;

- Falsifying a sudden abundance of products that leads to trading in such products at inappropriate prices that affect the economies of the remaining competitors;

- Preventing or obstructing the practice of any person's economic activity on the market or ceasing said activity at any time;

- Wholly or partly preventing a given person from obtaining products available on the market according to the parameters indicated in the Implementing Regulations;

- Selling products for lower than the actual cost thereof with the intention of harming competing producers;

- Influencing the tenders for selling or buying or providing or supplying products and services, whether in bids or auctions or supply offers; mutual offers of applicants shall not be deemed as aforementioned;

81 Id. art. 45.

82 Whoever discloses the identity of the whistleblower or his/her domicile shall be punished by imprisonment for a term not exceeding three years and a fine of not less than one thousand nor more than five thousand Kuwaiti Dinars, or by one of these two penalties. See id. art. 51.

83 Id. art. 53.

84 Law No. (10) of 2007 on the Protection of Competition art. 2. 
- Including provisions in terms of bids that designate the brands or categories of commodities to be purchased;

- Total or partial suspension of the processes of manufacture, modernization, distribution or marketing of commodities and services or placing restrictions or conditions on making those mentioned above available according to the parameters indicated in the Implementing Regulations; or

- Causing competitors to lose equal opportunities by discriminating between them in the conditions of sale or purchase deals without justification, or by leaking information to one competitor to exclude another. ${ }^{85}$

It is unclear why Kuwaiti legislators encumbered Nazaha with jurisdiction over such overwhelmingly widespread offenses. However, an Organ for Protection of Competition was established in 2012 with the authority: to receive notices, applications and complaints; to follow investigations and research procedures; to compile indications; and to investigate cases of agreements, contracts, and practices that harm competition. $^{86}$

\section{K. Offenses regarding the Disclosure of Commissions}

These offenses are outlined in Law No. (25) of 1996 on the Disclosure of Commission in connection with Government Contracts. According to this Law, all contracts entered into by any of the Government agencies, whether for supplies, public procurement, concessions, public works (including arms deals and any military materials) or any other contracts, irrespective of their type or their method of conclusion, and whose value is not less than one hundred thousand dinars, whether concluded through international or local tenders or through negotiation or direct award-should include an express stipulation of whether the party who contracted with any of the said agencies has paid or will pay, or has given or will give a commission in cash or inkind or a benefit of any kind to an intermediary, whether explicit or implicit in the contract. ${ }^{87}$

If a contract stipulates the payment of a commission, the party mentioned above should have an authorized agent with real or elected domicile in Kuwait; the contract should reveal the full name of the intermediary or his representative, their

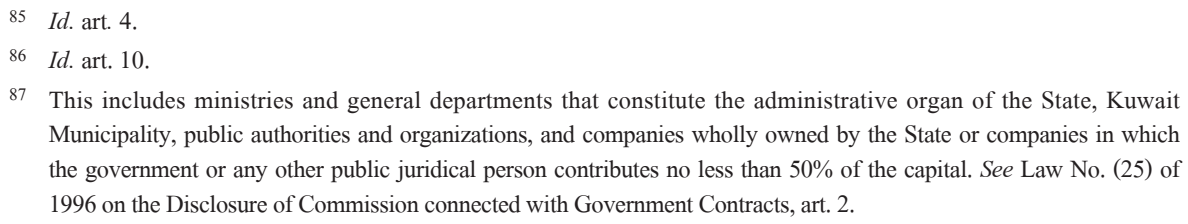
Municipality, public authorities and organizations, and companies wholly owned by the State or companies in which the government or any other public juridical person contributes no less than $50 \%$ of the capital. See Law No. (25) of 1996 on the Disclosure of Commission connected with Government Contracts, art. 2. 
title, profession or job, domicile, and place of business. In particular, it should also detail the amount or percentage of the commission, its type, the person to whom the commission has been or will be paid, and the place of payment. ${ }^{88}$

Moreover, the Law No. 25 adds that whoever pays or gives or receives in any capacity a commission, gift, grant or donation or the like, under any name, even if indirect, such as consideration for advice, administrative expenses, or any kind of service that realizes a material or moral benefit; or whoever promises or receives a promise related to the aforementioned in respect of the conclusion of contracts as described above or the execution thereof, shall have to submit within the following thirty days payment, cash, or a promise to the contracting agency in addition to a detailed written declaration of the commission amount, the currency of payment of such commission, and place and instrument of payment thereof. Said agency shall notify the State Audit Bureau thereof immediately after the declaration has been submitted together with a copy of it. ${ }^{89}$

Therefore, to protect the public fund, it is the duty of the State and all its citizens to disclose the commissions that will accrue to the beneficiaries' financial assets in the civil and military contracts concluded and its public persons and different agencies. This can be achieved by obligating the other contracting party to disclose the value of commissions, the nature and description of such commissions, the type of currency used, the place and instrument of payment, name(s) of the beneficiary or beneficiaries, titles, or jobs, domicile or place of residence, his/her role in achieving the deal, their activity, and the extent of their direct or indirect influence in concluding the deal. ${ }^{90}$

The criteria mentioned above aim to prevent manipulation that may lead to prejudice or robbery of public funds under a false legal umbrella while reducing the excess payment of commissions that may present a temptation to prejudice the public interest for personal ones. Therefore, this provision was specifically created and implemented to achieve the optimal target dictated by the duty to protect and safeguard inalienable public funds and to ensure the sound conclusion of government contracts, so that personal interest and the temptation to pursue personal interests can be avoided. Furthermore, the execution of constructions and public projects undertaken by the State are ensured to meet its needs through such contracts. ${ }^{91}$

89 Id. art. 3.

90 Explanatory Memorandum of the Draft Bill on Disclosure of Commissions Given under the Contracts Concluded with the State.

91 Id. 


\section{Other Forthcoming Offenses}

The final clause of Article 22 of Nazaha Law stipulates the offenses that fall within its jurisdiction, including a remarkably open-ended provision. To avoid the conclusive list method, which enumerates the relevant acts, this clause includes any offenses that may be committed in the future, as long they are considered corruption offenses, which are thereby subjected to Nazaha's jurisdiction.

\section{Ratione Personae}

According to Article 2 of the 2016 Nazaha Law, the people subject to personal jurisdiction are as follows:

1. The Head of Government (Prime Minister), deputies of the Prime Minister, the Ministers, and those who hold executive offices at the ministerial rank.

2. The President, deputy-president, and members of the National Assembly (Parliament).

3. The President and members of the Highest Judicial Council, President and justices of the Constitutional Court and the Technical Division of the Court, judges, members of the Public Prosecution, the President and members of the Fatwa and Legislation Authority, the Director-General and members of the General Administration of Investigations at the Ministry of Interior, the Legal Division of Kuwait Municipality, experts, arbitrators at the Ministry of Justice, liquidators, agents of creditors, receivers, notaries and the registrar at the Divisions of Real Estate Registration and Authentication at the Ministry of Justice.

4. The President and vice-president and members of the Municipal Council.

5. The presidents and members of boards, authorities, and committees that carry out executive functions, which a law, decree, or decision are issued by the Council of Ministers on the formation thereof or selection of their members.

6. The President of the Finance Controllers Body, his/her deputy, and heads of sectors and finance controllers.

7. Leaders who hold a group of leading positions in the general schedule pay scale (Senior-ranked positions/undersecretary/assistant undersecretary), and members of boards of directors and general administrators and their deputies or assistants and secretaries-general and their deputies or assistants in the public entities or institutions or any governmental agency.

8. Leaders' equivalents, such as heads of departments or administrative units and their deputies or members assigned to public entities and institutions. 
9. Directors of the divisions and their equivalents, such as heads of the organizational units.

10. This also applies to military personnel, diplomats and civilians in the ministries, governmental departments, public entities and institutions, and agencies with independent or supplementary budgets whenever they carry out the responsibilities or benefit from the privileges prescribed for the office, whether they hold the office regularly or temporarily.

11. The President, vice-president, members of the Board of Trustees, the SecretaryGeneral, Assistant Secretaries-General, directors, and the Kuwait AntiCorruption Authority's technical staff.

12. The President, vice-president, deputies, directors, and the State Audit Bureau of Kuwait's technical staff.

13. Representatives of the State in the Boards of Directors of the companies in which the State or one of the governmental agencies, public entities or institutions, or other public legal bodies directly share in a proportion not less than $25 \%$ of the capital.

14. Members of the boards of directors of sports authorities and cooperative societies. $^{92}$

The introductory sentences of Article 2 of Nazaha's regulations state that the provisions of the Law apply to and its legal practices of jurisdiction are only linked to these people, as its ratione personae. ${ }^{93}$ Therefore, any other persons who commit the crimes listed in Article 22 of the 2016 Nazaha Law will not fall within Nazaha's jurisdiction. These circumstances bear serious consequences, particularly concerning the crime of illicit gain, which exists solely in the Nazaha Law and has no similar provisions in Kuwaiti legal jurisprudence, because other non-listed public officials may commit this crime and go unpunished in their violation of the UNCAC provisions.

This understanding runs counter to other provisions of the 2016 Nazaha Law including Article 1 which defines a public official. The UNCAC's definition of a public official is broader than the listed official positions or seniority in Nazaha Law.

922016 Nazaha Law art. 2.

93 It should be noted that Nazaha has the legal jurisdiction only to conduct procedures of seizures and preliminary investigation. Therefore, it can refer cases to the public prosecution, which has exclusive responsibility for the investigation, disposition, and prosecution of all offenses stated in Nazaha Law and any other related offenses. See 2016 Nazaha Law art. 2. Thus, according to this provision, Nazaha has referred several cases that included many of the listed officials, https://www.nazaha.gov.kw/EN/Pages/default.aspx. One of the serious challenges that facing Nazaha and its effectiveness is the case involving some of the Royal Family members of Kuwait, especially the sons of the former Prime Minister, which involves the crime of money laundering of the stolen Malaysian money (1MBD). The question for Nazaha in this case is whether it will practice its jurisdiction over the case or it will refrain based on the facts that the accused is not a public official. For details, see Yasmena Al Mulla, 1MBD scandal: Kuwait royal family member arrested for money laundering, GuLF NeWs, July 11, 2020, https://gulfnews.com/world/gulf/kuwait/1mbd-scandal-kuwait-royalfamily-member-arrested-for-money-laundering-1.72538592. 
For example, the former includes all public officials working in government or any of its entities or authorities. By contrast, those stipulated in Nazaha Law include only high-ranking public officials.

In addition, the crimes listed in the 2016 Nazaha Law are public official-related offenses, such as bribery or abuse of power. However, there are crimes that may be committed by non-public officials. For example, crimes related to customs evasionas Nazaha Law states-are committed by, among others, the owners of the means of transport used for smuggling, the drivers and assistants involved, the owners or tenants of the shops and premises used to store contraband, or the beneficiaries who have been proven aware of the presence of contraband in their premises. The same finding applies to other offenses, such as money laundering, financing terrorism, tax evasion, unlawful acts of competition, and Offenses regarding the Disclosure of Commissions.

\section{Authority to Seize and Investigate}

Nazaha Law does not mention whatever types of jurisdiction to exercise its authority to seize and investigate the listed crimes therein. This may be because it exercises only seizures and preliminary investigation procedures, while the public prosecution has exclusive responsibility for the investigation, disposition, and prosecution of all offenses, whether or not they are referred by Nazaha.

However, the question of Nazaha's competence to exercise its procedures of seizures and preliminary investigation and then to refer cases to public prosecution, persists. Applying rules relevant to Kuwait, the traditional legal basis for jurisdiction is stipulated in the 1960 Kuwaiti Penal Code.

\section{A. Territorial Jurisdiction}

According to the 1960 Kuwaiti Penal Code, any crimes committed in the territory-in its broad definition-shall be subject to legal jurisdiction. Article 11 states: "This Law shall apply to any person who commits a crime in the territory of the State of Kuwait and its dependencies. It applies to any person who commits an act outside Kuwait's territory if that makes him or her an original or accomplice of all of that act or part of Kuwait's territory." 94 
This conforms to the UNCAC's restated territorial jurisdiction in its classic application as a mandatory jurisdiction. According to the UNCAC, State entities are obliged to establish their jurisdictions over the offenses committed in their territories or onboard vessels flying their flags or aircraft that are registered under their laws at the time of the offenses' commission.

The UNCAC also provides for territorial jurisdiction, though this provision is optional. It covers the offenses concerning participation in, association with, conspiracy to commit, attempt to commit and to aid, abetting, facilitating, and counseling the laundering of proceeds of crime, as defined by Article 23 of the UNCAC, committed in the territory of the State party. ${ }^{95}$

\section{B. Personal Jurisdiction}

Article 12 of the 1960 Kuwaiti Penal Code states: "The provisions of this Law shall also apply to any person of Kuwaiti nationality who commits outside Kuwait a punishable act following the provisions of this Law and by the law applicable in the place where the act was committed if returned to Kuwait without being acquitted by the concerned foreign court." ${ }^{, 96}$ Thus, according to this article, the person will be subject to Kuwaiti legal jurisdiction if the following conditions are met.

First, s/he is a Kuwaiti national. Just habitual residence in Kuwait, whether stateless or not, is insufficient. Second, the act in question is criminalized in both Kuwait and the host country. Finally, without being prosecuted and acquitted by the concerned foreign court, they traveled to the third country and are not subject to Kuwaiti legal jurisdiction, even if they were not acquitted by the country in which the crime was committed.

Although the UNCAC made it optional for states to establish their personal jurisdictions over their nationals, this jurisdiction becomes obligatory when the alleged offender is present in the territory of a State that does not extradite them on the grounds that they are a national of the said territory. ${ }^{97}$ Therefore, if the refusal of extradition is based on other reasons, the exercise of personal jurisdiction will be

95 UNCAC art. 42(c). See C. Ryngaert, Territorial Jurisdiction over Cross-Frontier Offences: Revisiting Problem of International Criminal Law, 9 INT'L CRIM. L. Rev. 202-9 (2009).

961960 Kuwaiti Penal Code art. 12.

97 UNCAC art. 42(3). It should be noted that many States are prohibited by their legislations or constitutions to extradite their nationals. See e.g., KuwAit Const. 1962, art. 28. Therefore, for UNCAC to ensure that justice is served in these cases, it requires a State that refuses to extradite a national to submit the case to its competent authorities for prosecution. See United Nations Office on Drugs and Crime, Legislative Guide for the Implementation of UNCAC, $\mathbf{q}$ 549-551 \& 564-566 (2d ed. 2012), https://www.unodc.org/documents/treaties/UNCAC/Publications/LegislativeGuide/ UNCAC_Legislative_Guide_E.pdf. 
optional. The UNCAC also adds that when a stateless person who has their habitual residence in their territories, this provides a legal basis for States Parties to exercise their optional personal jurisdiction. ${ }^{98}$

It should be noted that the previous argument concerns the personal jurisdiction in its traditional aspect (i.e., if the perpetrator of the crime is a national of the concerned State). Conversely, passive personal jurisdiction is absent from Kuwait's penal laws. However, this is not the case for the UNCAC, although it was made optional for States Parties. ${ }^{99}$

\section{Protective Jurisdiction}

No general principle of protective jurisdiction is articulated in the 1960 Kuwaiti Penal Code per se. However, it includes an isolated provision related to specific crimes, as considered by the 2016 Nazaha Law, to be "corrupt crimes." As mentioned above, offenses against public funds are regulated by Law No. (1) of 1993 of the Protection of Public Funds. According to this law, the protection of Kuwaiti Public Funds, defined under Article 2, will extend to include anyone who commits any of the listed crimes therein, even if the offenses are committed outside Kuwait. ${ }^{100}$ However, the UNCAC made it optional for states to exercise their protective jurisdiction by stating that the specific entity may establish its jurisdiction if "the offense is committed against it."101

\section{Aut Dedere Aut Judicare Jurisdiction}

In its regular usage, the latin phrase aut dedere aut judicare means that a State is obliged to try the alleged offender for crimes listed in the UNCAC when they are present in the State's territory and refuses to extradite them. A variation on the typical application of the principle of aut dedere aut judicare in international conventions relating to international crimes made it obligatory. ${ }^{102}$ The UNCAC made this optional for states unless the alleged offender is not extradited because that person a

98 UNCAC art. 42(2) (stating that: “... a State Party may also establish its jurisdiction over any such offense when: ...... (b) the offense is committed by a national of that State Party or a stateless person who has his or her habitual residence in its territory...")

99 UNCAC art. 42(2)(a).

1001993 Law, supra note 6 art. 4.

101 UNCAC art. 42(2)(d).

102 For example, Article 5 of the 1984 UN Convention against Torture states: “... 2. Each State Party shall likewise take such measures as may be necessary to establish its jurisdiction over such offenses in cases where the alleged offender is present in any territory under its jurisdiction, and it does not extradite him pursuant ..." 
national. $^{103}$

In Kuwait, however, the situation is different because it is the official delegate to the Arab Convention against Corruption of 2010 (ACC). ${ }^{104}$ According to this regional instrument, which was ratified by Kuwait in 2013, States are obliged to establish their jurisdiction when the person accused of the criminalized actions under the Convention is present in their territory and the State in question does not extradite them. ${ }^{105}$

ACC is not only legally binding Kuwait from an international legal perspective, but it also nationally constitutes a basis for the obligations and rights of individuals, legal persons, and authorities. According to Article 70 of Kuwait's Constitution, international treaties and conventions ratified by Kuwait have the same legal force as parliament laws. ${ }^{106}$ ACC was ratified by Law No. (92) of 2013 on the Approval of the Arab Convention against Corruption, meaning that the Convention's provisions are legally binding both domestically and internationally.

Unlike the UNCAC, which made personal jurisdiction optional for States Parties, whether on the nationality principle or passive nationality principle, ACC made it obligatory. Article 9 (1) of the Convention provides that:

The crimes that are stated in this Convention shall be subject to the jurisdiction of the state party in any of the following circumstances ... where the commission of the offense is against the interests of the state party or one of its citizens or residents ... where the offense was committed by a citizen or resident of the state party, or by a stateless person who holds normal residence in its territory. ${ }^{107}$

As can be seen from the provisions above, legal jurisdiction shall be established even if any of the alleged crimes are committed not only against a national of the state entity but also against a resident, regardless of their nationality. The same rules may apply when the resident is the alleged perpetrator of any of the prescribed crimes.

103 UNCAC art. 42(4). A similar provision is also included in the United Nations Convention against Transnational Organized Crime of 2000 (CATOC). CATOC and its three Protocols oblige States Parties to criminalize four particular offenses connected to organized criminal activities, among which are money-laundering and bribery, both active and passive. See 40 I.L.M. 334 (2001). See also I. Bantekas, Corruption as an International Crime and Crime against Humanity: An Outline of Supplementary Criminal Justice Policies, 4 J. INT'L CrIM. Just. 466-84 (2006).

104 Signed on Dec. 21, 2010 by 21 Arabic States and ratified by 12 States, including Kuwait.

105 Arab Convention against Corruption, art. 9(2).

106 Kuwait Const. 1962, art. 70.

107 Arab Convention against Corruption, art 9(1). 


\section{Conclusion}

In conclusion, not all crimes that constitute corruption are covered by international legal instruments such as the UNCAC. The following corrupt acts are not regulated by the UNCAC: extortion-the use of threat of violence or the exposure of damaging information to induce cooperation or compliance; usage of secret information gained by position to personal investment; favoritism or cronyism by using one's power to make decisions on the basis of personal relationships rather than on objective grounds; electoral malpractice, such as vote-buying or election rigging; illegal campaign contributions; clientelism and patronage, such as politicians giving material favors in exchange for citizen support; or corruption in international nongovernmental organizations or political parties.

Similarly, the 2016 Nazaha Law is not expected to criminalize all acts of corruption, but it should, at least, include all corrupt acts articulated in the UNCAC, considering that it is an implementation tool of the UNCAC (as noted in its preamble). Moreover, as a new authority with limited resources, Nazaha should not be incumbent with so many offenses, including tax evasion, smuggling, false testimony, perjury, counterfeiting, forgery, and terrorism financing, because these offenses are already subject to the jurisdiction of a competent judicial authority, through public prosecution. Although, in practice, Nazaha confines itself to offenses related to personal jurisdiction, we believe that such practice contravenes Nazaha Law, and goes against the reality because these offenses are not crimes related to public officials. Therefore, one may expect that at any time in the future, this practice may be amended to be consistent with its law for reasonable understanding. Rather than covering offenses that already exist, Nazaha Law should be amended to include crimes of corruption in the private sector, as Kuwait is in the process of privatizing many essential services and interests to cover all aspects of the crime of illicit gain, which did not exist in the national legal jurisprudence. It should also be amended to include all unjustified increases in assets of public officials, as stated by the UNCAC, not just the listed officials already spelled out by the Nazaha Law.

Finally, it must be clear and understandable for Nazaha or other judicial authorities in Kuwait that corrupt offenses (e.g., bribery of public officials, trading influence, abuse of functions, illicit gain, money laundering, or obstruction of justice), whether criminalized by the 2016 Nazaha Law or under other penal laws in Kuwait, must be subject to the jurisdiction of Nazaha or other judicial authorities when committed by a Kuwaiti national abroad, even if such acts are not punishable under 
the laws of the host state. Besides complying with ACC's obligatory provisions, this follows Kuwaiti domestic law, since international conventions ratified by Kuwait also enjoy the full legal binding force inside the country.

Received: August 15, 2020

Modified: October 1, 2020

Accepted: November 15, 2020 
